\title{
Microglandular Adenocarcinoma of the Endometrium: Case Report
}

\author{
Endometriumun \\ Mikroglandüler Adenokarsinomu
}

\author{
Perihan Özlem DOĞAN, ${ }^{a}$ \\ Hamide SAYAR, ${ }^{a}$ \\ Gürkan KIRAN, ${ }^{b}$ \\ Abdullah AYDIN, ${ }^{c}$ \\ Emel CANAZ ${ }^{b}$ \\ Departments of \\ apathology, \\ ${ }^{\text {'} G y n e c o l o g y}$ and Obstetrics, \\ Kahramanmaraş Sütçü İmam University \\ Faculty of Medicine, Kahramanmaraş \\ 'Department of Pathology, \\ İstanbul Medeniyet University \\ Faculty of Medicine, İstanbul
}

Geliş Tarihi/Received: 20.01 .2014

Kabul Tarihi/Accepted: 25.04.2014

An abstract presentation of this case was accepted to 18th International Meeting of the European Society of Gynaecological Oncology (ESGO) 2013.

Yazışma Adresi/Correspondence: Perihan Özlem DOĞAN

Kahramanmaraş Sütçü İmam University

Faculty of Medicine,

Department of Pathology,

Kahramanmaraș,

TÜRKIYE/TURKEY

tadby@ hotmail.com

\begin{abstract}
We report a case of endometrial microglandular adenocarcinoma which can be confused with microglandular hyperplasia and mucinous adenocarcinoma of the cervix and mucinous proliferation of the endometrium. A 54-year-old postmenopausal woman presented with vaginal bleeding. Histologically, endometrial biopsy was characterized by closely packed microglandular and mucinous glandular areas, which is lined by cuboidal and columnar cells. There was a multitude of neutrophils in microglandular lumens and stroma. Immunohistochemically, focal positivity for vimentin, CEA, estrogen and progesterone receptors were seen. The histology was suspicious for malignancy that might be compatible with microglandular adenocarcinoma of the endometrium resembling microglandular hyperplasia of the cervix. In the final workout of the hysterectomy specimen, we determined a superficial microglandular adenocarcinoma with no myometrial invasion. Several tubal, eosinophilic syncytial and squamous metaplasia areas were present. Pathologists require sufficient clinical information, morphologic experience and immunohistochemical assistance to make the correct pathological diagnosis in such confounding neoplasms.
\end{abstract}

Key Words: Endometrial neoplasms; adenocarcinoma; hyperplasia; metaplasia

ÖZET Endometriumun müsinöz proliferasyonu, serviksin müsinöz adenokarsinomu ve mikrog landüler proliferasyonu ile karışabilen bir endometrial mikroglandüler adenokarsinom vakası sunduk. 54 yaşında postmenopozal kadın hasta vajinal kanama ile başvurdu. Histolojik olarak endometrial küretaj, küboidal ve kolumnar hücrelerle döşeli, sıkı paketlenmiş mikroglandüler ve müsinöz glandüler alanlarla karakterizeydi. Mikroglandüler lümenlerde ve stromada çok sayıda nötrofil mevcuttu. İmmünohistokimyasal olarak, Vimentin, CEA, Östrojen ve Progesteron reseptörleri ile fokal pozitivite izlendi. Histolojisi serviksin mikroglandüler hiperplazisine benzeyen endometrial mikroglandüler adenokarsinoma benzerliği yönüyle malignensi açısından şüpheliydi. Ardından gelen histerektomi spesmeninde, miyometrial invazyon göstermeyen yüzeyel bir mikroglandüler adenokarsinom belirlendi. Çok sayıda tubal, eozinofilik sinsityal ve skuamöz metaplazi alanları izlendi. Böyle şüpheli neoplazmların doğru patolojik tanısı için patologların klinik bilgi, morfolojik inceleme ve immünohistokimyasal destek konusunda dikkatli olmaları gerekmektedir.

Anahtar Kelimeler: Endometriyal tümörler; adenokarsinom; hiperplazi; metaplazi

Turkiye Klinikleri J Gynecol Obst 2016;26(2):114-8

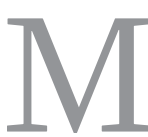
ucinous microglandular adenocarcinoma (MGA) is an uncommon subtype of endometrial adenocarcinoma which can be confused with mucinous adenocarcinoma (MUC-AD) and microglandular hyperplasia of the cervix or mucinous proliferations of the endometrium..$^{1-3}$ This neoplasm can mimic microglandular hyperplasia (MGH) particularly, which is characterized by closely packed glands lined by cuboidal or colum- 
nar epithelium without intervening stroma. ${ }^{2}$ The histologic features of MGH may not be distinguished from malignant process, particularly in endometrial sampling. Initially, Young and Scully ${ }^{1}$ described five cases of uterine carcinoma simulating microglandular hyperplasia. To our knowledge, about 23 cases were reported in the literature. We described a novel case of MGA which is localized in only superficial layer of the endometrium. There is no conventional carcinoma as mucinous or endometrioid type that accompany with MGA unlike other cases in literature. Also the present case contains tubal, eosinophilic syncytial and squamous metaplasias in common areas.

\section{CASE REPORT}

Informed consent was obtained from the patient. A 54-year-old obese postmenopausal woman, gravida 2, para 2, was referred to our gynecology clinic with two months history of intermittent vaginal bleeding. She had a history of coronary artery disease and thyroidectomy operation. She had not been using any exogenous hormone therapy. Her laboratory data were in normal ranges. In ultrasonographic examination endometrial line was seen at $13.6 \mathrm{~mm}$ in thickness. Cervical smear revealed only moderate inflammation. Endometrial curettage was performed and histopathological analysis of the specimen showed a formation characterized by closely packed microglandular and mucinous glandular spaces, micropapillary formations and squamous areas (Figure 1). The glands were lined by cuboidal or columnar cells with pale eosinophylic or clear cytoplasm. The nuclei, commonly with prominent nucleoli were oval-round in shape and exhibited moderate atypia. Mitoses were rare. There was a multitude of neutrophils in the microglandular and mucinous glandular lumens and lymphocytic infiltrate was present in the stroma.

Immunohistochemically, focal strong positivity for vimentin, diffuse positivity for $34 \beta 12$ and CK-7, focal positivity for $\mathrm{p} 53$ were seen in the neoplastic cells (Figure 2A). CEA positivity was shown in most of the cell's cytoplasm and the lumens of some glands (Figure 2B). Estrogen and proges-

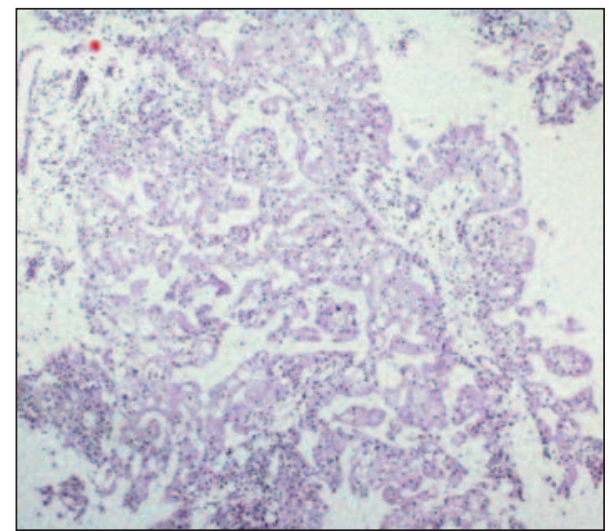

FIGURE 1: Curettage specimen (hematoxylin-eosin stain). The neoplasm shows irregular packed microglandular spaces with numerous neutrophils and mucinous glandular spaces in the curettage specimen (magnification $\mathrm{X} 40)$.

terone receptor antibodies stained positively $5-10 \%$ and Ki-67 immunoreactivity was observed in 3-4\% of the neoplastic cells (Figure 2C-E). There were some microglandular areas with negative staining for vimentin. The invasion could not be assessed in the insufficient and fragmented curettage specimen. So, it is reported that the endometrial specimen was suspicious for malignancy which may be compatible with MGA of endometrium but undistinguished from MGH of the cervix.

Afterwards, patient underwent total abdominal hysterectomy and bilateral salphingooopherectomy following peritoneal washing and frozen section was performed intraoperatively. Preliminary histological study in frozen section revealed adenocarcinoma of the endometrium and staging surgery with harvasting of the pelvic lymph nodes and omentectomy was done. In the hysterectomy specimen $(11 \times 10 \times 8 \mathrm{~cm})$, a pink polipoid lesion which is $0.5 \mathrm{~cm}$ in diameter was seen at fundus. The other endometrial areas were determined in a flat appearance macroscopically. Several Nabothian cysts were seen in the cervix which was normal otherwise. The right ovary $(3.5 \times 2 \times 2 \mathrm{~cm})$ and the left ovary $(3.7 \times 2 \times 2 \mathrm{~cm})$ showed no conspicuous changes.

On microscopic examination, a residual adenocarcinoma with the same features that observed in the endometrial currettage material was seen in 

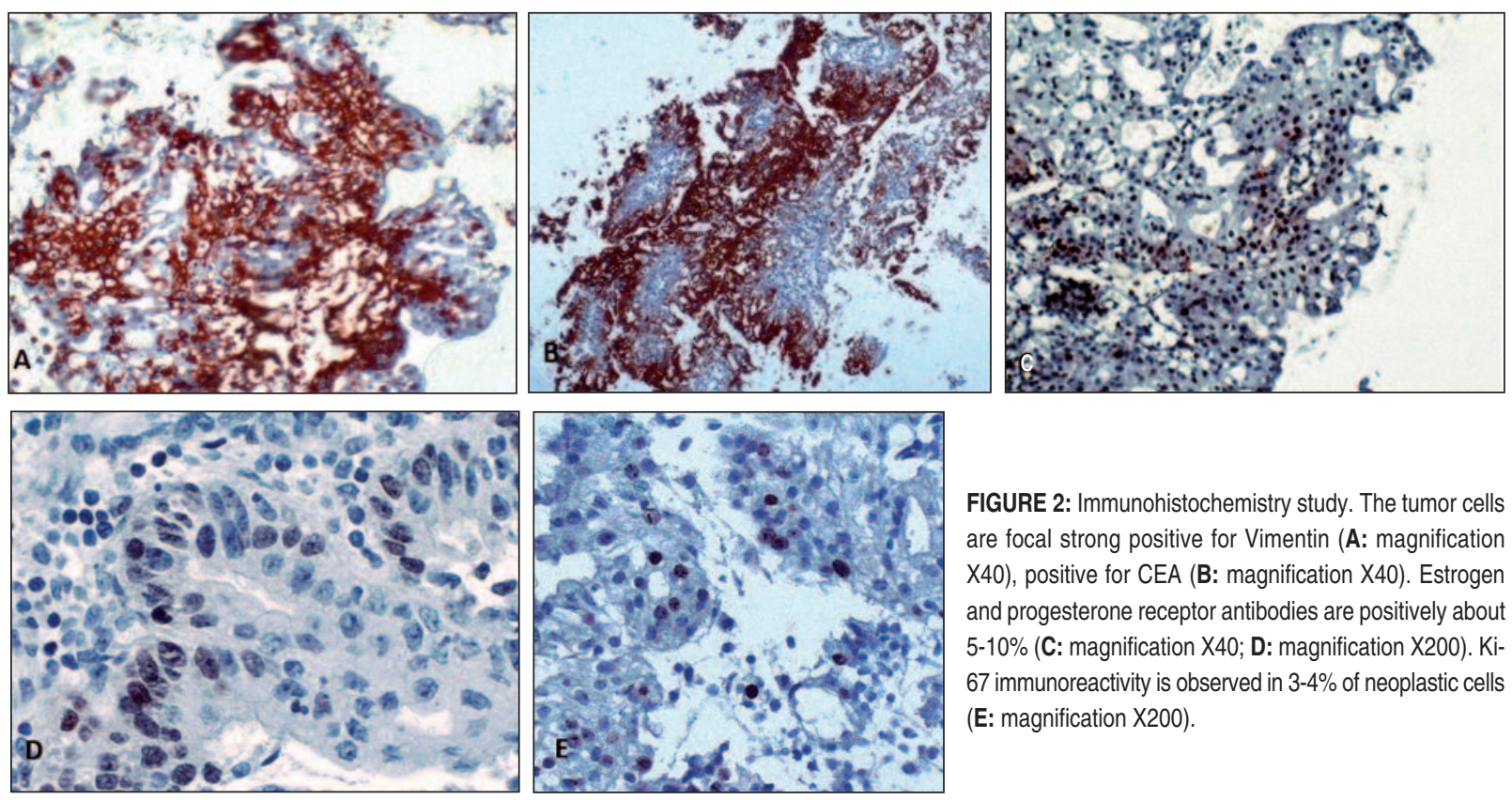

FIGURE 2: Immunohistochemistry study. The tumor cells are focal strong positive for Vimentin (A: magnification X40), positive for CEA (B: magnification X40). Estrogen and progesterone receptor antibodies are positively about 5-10\% (C: magnification X40; D: magnification X200). Ki67 immunoreactivity is observed in $3-4 \%$ of neoplastic cells (E: magnification X200).

only superficial layer of the endometrium (Figure 3A). Also complex hyperplasia with focal atypia and simple hyperplasia without atypia were observed in different endometrial areas (Figure 3B). Furthermore, we determined several glands that demonstrates tubal metaplasia, eosinophilic syncytial metaplasia and squamous metaplasia (Figure 3C, D). There was no myometrial invasion. Immunohistochemical results were similar to those found in the curettage specimen. In addition to immunohistochemistry, all stains for mucicarmine, Alcian blue and PAS showed abundant luminal mucin and occasional mucin droplets in the cytoplasm (Figure 3E). The peritoneal washing, lymph nodes and omentum were negative for metastasis. Finally the diagnosis was made as nuclear grade 1, architectural grade 1, FIGO grade 1 tumor of MGA, so no adjuvant therapy was administered. Nine months following her hysterectomy, no evidence of disease was detected.

\section{DISCUSSION}

Microglandular adenocarcinoma is a rare subtype of mucinous carcinoma of the endometrium which shows microglandular, mucinous and squamous features, so it can be mistaken for other benign and malignant lesions of the endometrium and the cervix. MGA was initially described by Young and Scully in $1992 .{ }^{1}$ In the literature the age range of the patients was 37-84 years and all of the cases were postmenopausal except the case of cervical adenocarcinoma. ${ }^{1,4-9}$ All patients were referred to the hospital with the complaints of vaginal spotting, discharge or bleeding. Medication with exogenous hormones was reported in only six of the cases. Our patient was not using exogenous hormone therapy. A history of diabetes mellitus and hypertension was reported in only two cases. ${ }^{4,5}$ Two of the patients were obese, including the current case. ${ }^{4}$

In the assessment of endometrial curettage specimens of the cases that formerly reported, six of them were misinterpreted as benign or uncertain histology whether benign or malignant. ${ }^{1}$ Two of cases were misdiagnosed as MGH. ${ }^{6}$ One of cases was initially mistaken for cervical mucinous adenocarcinoma. ${ }^{10} \mathrm{We}$ reported the curettage material as "suspicious for malignancy that might be compatible with MGA of the endometrium or MGH of the cervix". Apparently, this neoplasm can mimic a cervical microglandular hyperplasia, mucinous adenocarcinoma of the cervix or mucinous proliferation of the endometrium in the examination of curettage specimen. 


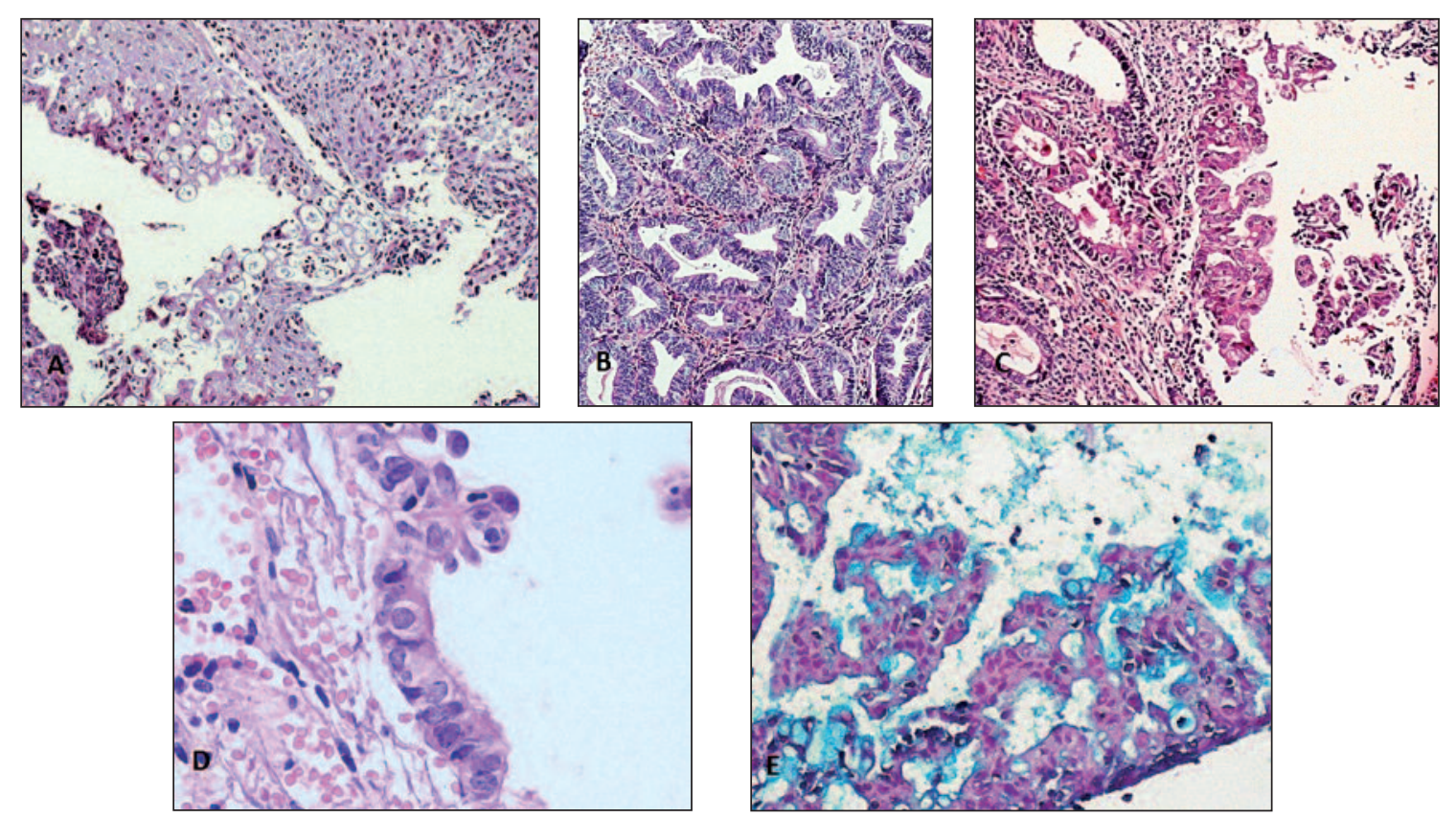

FIGURE 3: Residual microglandular adenocarcinoma (hematoxylin-eosin). Hysterectomy specimen shows residual adenocarcinoma (A: magnification X100). Complex hyperplasia with focal atypia (B: magnification X100). Several glands with eosinophilic syncytial metaplasia (C: magnification X100) and tubal metaplasia (D: magnification X100). Alcian blue shows abundant mucinous glandular structures (E: magnification X200).

Clinically, MGH is usually associated with young age and hormone therapy, but MGA usually occurs in the postmenopausal women. ${ }^{11}$ So the patient's age and postmenopausal status can be a clue for differential diagnosis. Histologically, both MGH and MGA present microglandular pattern, mucin production, accumulation of neutrophils in the gland lumen and stroma, mild nuclear atypia and rare mitotic figures. Contrarily, nuclear atypia and mitotic figures are more prominent in the MGA. Atypic mitotic figures are not seen in the MGH. ${ }^{6}$ Additionally it can be useful to realize that in some cases of MGH subnuclear vacuoles are present, which are absent in MGA. ${ }^{11}$

Immunohistochemically, vimentin staining is important for the differential diagnosis, which is positive in MGA and negative in MGH. ${ }^{2}$ The present case was focal positive for vimentin. Both MGA and MGH have variable expression of estrogen and progesteron receptors. ${ }^{2}$ Some studies reported that CEA staining was usually positive in adenocarcinomas of the endometrium and endocervix, but negative in mucinous adenocarcinoma of the endometrium and MGH of the cervix. ${ }^{6,7}$ Contrarily,
Qiu et al. found negative CEA staining in all their MGA and MGH cases. ${ }^{2}$ Therefore, immunstaining with either CEA, estrogen, progesteron or p53 were not showed to be beneficial in differential diagnosis. Chekmareva et al. reported that p16, CD10 and CD34 immunostaining may be favorable in distinguishing MUC-AD and MGA of the endometrium from benign endocervical lesions. ${ }^{8}$ As reported, MUC-AD and MGA cases were positive for $\mathrm{p} 16$, whereas none of the cases which have benign mucinous endocervical epithelial lesion and MGH showed p16 positivity. Also, Barroeta et al. showed that "CD34- dominant phenotype" of stromal cells staining was consistent with the cervical origin of the tissue however "CD10- dominant phenotype" of stromal cells complied with the endometrial origin of the tissue and the study of Chekmareva et al. confirmed these findings. ${ }^{8,12}$

MGA which can also be named as MGH-like carcinoma, should be differentiated from also benign mucinous proliferation of the endometrium. The simple glandular architecture with mucin containing cells, absense of nuclear atypia and epithelial stratification support benign mucinous proliferation. ${ }^{3}$ 
In all cases in the literature, residual carcinomas were seen in the hysterectomy specimens as in the present case. All authors found conventional carcinomas as mucinous or endometrioid type accompanying MGH-like carcinoma. These findings support the idea that the microglandular pattern represents a line of differentiation that is more mature and less aggressive in comparison with conventional carcinoma and this microglandular pattern usually occurs on the tumor surface where an area permits a proliferation of noninvasive cells. ${ }^{4}$ The studies of Young and Scully and Fukunaga supported this argument but Zaloudek et al. and McCluggage found MGH-like patterns in invasive areas of the tumor. ${ }^{1,6,7,13}$ Contrary to all of them we found only MGH-like carcinoma in superficial layer of the endometrium in the hysterectomy specimen. There was no evidence of any other accompanying carcinoma. But focal atypical complex hyperplasia and simple hyperplasia without atypia were present. It demonstrates that MGH-like carcinoma can be seen without any conventional carcinomas and it can develop from endometrial hyperplasia. Also we reported severe tubal and eosinophilic syncytial metaplasia areas adjacent to the tumor that might be the first case in the literature.

In summary, when a MGH-like proliferation with cytologic atypia is detected in the endometrial curettage specimen of a postmenopausal woman, the pathologists must be alert for MGA of the endometrium. Hence, at least a vimentin, p16 and CEA staining can be crucial. In addition, MGA can be found in only superficial layer of the endometrium, no accompanying conventional carcinoma can be seen and many different metaplasia areas can accompany to the tumor as in the case we presented.

\section{REFERENCES}

1. Young RH, Scully RE. Uterine carcinomas simulating microglandular hyperplasia. A report of six cases. Am J Surg Pathol 1992;16(11):1092-7.

2. Qiu W, Mittal K. Comparison of morphologic and immunohistochemical features of cervical microglandular hyperplasia with low-grade mucinous adenocarcinoma of the endometrium. Int $\mathrm{J}$ Gynecol Pathol 2003;22(3):261-5.

3. Nucci MR, Prasad CJ, Crum CP, Mutter GL. Mucinous endometrial epithelial proliferations: a morphologic spectrum of changes with diverse clinical significance. Mod Pathol 1999;12(12):1137-42.

4. Zamecnik M, Skalova A, Opatrny V. Microglandular adenocarcinoma of the uterus mimicking microglandular cervical hyperplasia. Ann Diagn Pathol 2003;7(3):180-6.

5. Giordano G, D'Adda T, Gnetti L, Merisio C,
Melpignano M. Endometrial mucinous microglandular adenocarcinoma: morphologic, immunohistochemical features, and emphasis in the human papillomavirus status. Int J Gynecol Pathol 2006;25(1):77-82.

6. Zaloudek C, Hayashi GM, Ryan IP, Powell $\mathrm{CB}$, Miller TR. Microglandular adenocarcinoma of the endometrium: a form of mucinous adenocarcinoma that may be confused with microglandular hyperplasia of the cervix. Int $\mathrm{J}$ Gynecol Pathol 1997;16(1):52-9.

7. Fukunaga M. Mucinous endometrial adenocarcinoma simulating microglandular hyperplasia of the cervix. Pathol Int 2000;50(7):541-5.

8. Chekmareva M, Ellenson LH, Pirog EC. Immunohistochemical differences between mucinous and microglandular adenocarcinomas of the endometrium and benign endocervical epithelium. Int $\mathrm{J}$ Gynecol Pathol 2008;27(4):547-54.
9. Da Forno PD, McGregor AH, Brown LJ. Microglandular hyperplasia: a pitfall in the diagnosis of microglandular type endometrioid adenocarcinoma. Histopathology 2005;46(3):346-8.

10. Karateke A, Haliloglu B, Atay V, Gurbuz A, Kir $G$. A case of microglandular adenocarcinoma of the endometrium. Gynecol Oncol 2005;99(3):778-81.

11. Taylor HB, Irey NS, Norris HJ. Atypical endocervical hyperplasia in women taking oral contraceptives. JAMA 1967;202(7):637-9.

12. Barroeta JE, Pasha TL, Acs G, Zhang PJ. Immunoprofile of endocervical and endometrial stromal cells and its potential application in localization of tumor involvement. Int J Gynecol Pathol 2007;26(1):76-82.

13. McCluggage WG, Perenyei M. Microglandular adenocarcinoma of the endometrium. Histopathology 2000;37(3):285-7. 